\title{
IMPLEMENTASI SUPERVISI AKADEMIK PADA MAN INSAN CENDEKIA PROVINSI JAMBI
}

\author{
Mohamad Muspawi \\ Fakultas Keguruan dan Ilmu Pendidikan, Universitas Jambi \\ Jl. Lintas Jambi - Muara Bulian Km. 15, Mendalo Darat, \\ Jambi Luar Kota, Kota Jambi, Jambi 36122 \\ Email: muspawi01@gmail.com \\ DOI: $10.29313 /$ tjpi.v6i2.3181
}

Accepted: November 7th, 2017. Approved: January 18th, 2018. Published: January 18th, 2018

\begin{abstract}
This study aims to determine the condition of implementation of academic supervision at MAN Insan Cendekia Jambi province. Where the manners of MAN Insan Cendekia Jambi province is a reference institution of Islamicbased education in Jambi province regarding institutional quality. The research method used is a descriptive qualitative method, which the researcher describes the research findings in narrative and what is. Data collection techniques used are observation techniques, documentation, and interviews. To check the validity of data then the authors do diligence observation, triangulation, member check, audit trail. And to analyze the data then the authors review and reduce data, data unitization, data categorization, and interpretation of data. The results of the research indicate that: 1) Implementation of academic supervision in MAN Insan Cendekia Jambi Province implemented in the form as follows: a) Supervision based on direct observation of teaching activities in the classroom; b) Supervision with daily work review; c) Supervision with inspection of teaching equipment; d) Supervision with academic dialogue; e) Supervision through questionnaires. And 2). Obstacles implementation of academic supervision in MAN Insan Cendekia Jambi Province is the number of duties and other responsibilities of the head of the madrasah. Based on the results of research can be concluded that the implementation of academic supervision in MAN Insan Cendekia Jambi Province has been implemented well to produce teacher performance is also good.
\end{abstract}

Keywords: Implementation, Supervision, Academic.

ABSTRAK

Penelitian ini bertujuan untuk mengetahui kondisi implementasi supervisi akademik pada MAN Insan Cendekia provinsi Jambi. Dimana kebaradaan MAN Insan Cendekia provinsi Jambi merupakan rujukan lembaga pendidikan berbasis agama Islam di provinsi Jambi dalam hal kualitas kelembagaannya. Metode penelitian yang digunakan adalah metode kualitatif deskriptif, yang mana peneliti menguraikan temuan penelitian secara naratif dan apa adanya. Teknik pengumpulan data yang digunakan adalab teknik obervasi, dokumentasi, dan wawancara. Untuk mengecek validitas data maka penulis melakukan ketekunan pengamatan, triangulasi, member check, audit trail. Dan untuk menganalisis data maka penulis melakukan penelaahan dan reduksi data, unitisasi data, kategorisasi data, dan interpretasi data. Hasil penelitian menunjukkan bahwa: 1) Implementasi Implementasi supervisi akademik di MAN Insan Cendekia Provinsi Jambi dilaksanakan dalam bentuk sebagai berikut: a) Supervisi berdasarkan pengamatan langsung kegiatan mengajar di kelas; b) Supervisi dengan peninjauan kerja harian; c) Supervisi dengan pemeriksaan perlengkapan mengajar; d) Supervisi dengan dialog akademis; e) Supervisi melalui pengisian angket. dan 2). Kendala implementasi supervisi akademik di MAN Insan Cendekia Provinsi Jambi adalah Banyaknya tugas dan tanggung jawab lain dari kepala madrasah. Berdasarkan hasil penlitian tersebut dapat disimpulkan bahwa implementasi supervisi akademik di MAN Insan Cendekia Provinsi Jambi telah terlaksana dengan baik sehingga menghasilkan kinerja guru yang juga baik.

Kata Kunci: Implementasi, Supervisi, Akademik. 


\section{PENDAHULUAN}

Kesuksesan sebuah sekolah dipengaruhi oleh banyak hal, salah satunya adalah peran supervisor dalam mensupervisi sekolah tersebut. Supervisi adalah suatu aktivitas pembinaan yang direncanakan untuk membantu para guru dan pegawai sekolah lainnya dalam melakukan pekerjaan mereka secara efektif (Purwanto, 2008: 76). Sedangkan supervisor adalah seseorang yang diberikan kewenangan untuk melakukan supervisi.

Kehadiran supervisi di sebuah sekolah merupakan suatu kegiatan yang sangat diperlukan, karena sesuai dengan tujuannya sebagaimana yang dikatakan oleh Arikunto (2007: 40) bahwa tujuan supervisi di sekolah adalah untuk memberikan bantuan teknis kepada guru dan staf sekolah yang lain, agar personil tersebut dapat meningkatkan kualitas kinerjanya.

Pihak yang berhak menjadi supervisor selain dari pengawas dari dinas pendidikan yaitu kepala sekolah. Yang mana menurut Priansa dan Somad (2014: 93) salah satu peran utama kepala sekolah sebagai supervisor pendidikan bagi guru adalah membantu atau membina guru agar lebih profesional dalam melaksanakan proses pembelajaran melalui fungsi supervisi dalam bentuk penelitian, penilaian, perbaikan dan peningkatan, sehingga kualitas pembelajaran menjadi lebih baik.

$$
\text { Kegiatan supervisi yang }
$$

dilaksanakan oleh kepala sekolah di sekolah melingkupi berbagai hal, antara lain supervisi akademik. Supervisi akademik lebih fokus kepada urusan persiapan dan pelaksanaan kegiatan belajar mengajar baik di kelas maupun di luar kelas.

Fakta lapangan sementara, terlihat bahwa MAN Insan Cendekia Provinsi Jambi mejadi salah satu ikon pendidikan provinsi Jambi. MAN Insan Cendekia Provinsi Jambi tampil dengan kualitas yang menjanjikan, saat ini MAN Insan Cendekia Provinsi Jambi merupakan salah satu sekolah memiliki daya tarik kuat bagi masyarakat, sehingga masyarakat begitu yang ingin menyekolah anak mereka di MAN tersebut.

Kesuksesan yang ditunjukkan oleh MAN Insan Cendekia Provinsi Jambi tentu didukung oleh berbagai faktor, antara lain tentunya didukung oleh pengelolaan yang baik dari kepala sekolahnya. Oleh karenanya, penulis merasa tertarik untuk melihat secara prosedur ilmiah bagaimana sesungguhnya pelaksanakan pengelolaan yang dilakukan oleh kepala sekolah terutama tentang pelaksanaan supervisi akademik di MAN Insan Cendekia Provinsi Jambi tersebut.

$$
\text { Mencermati latar belakang }
$$

permasalahan yang telah penulis kemukakan, penulis merasa tertarik untuk mengadakan penelitian dengan judul: "Implementasi Supervisi Akademik di MAN Insan Cendekia Provinsi Jambi"

\section{METODOLOGI PENELITIAN}

Penelitian ini menggunakan pendekatan kualitatif yang bertujuan untuk mengkaji permasalahan dan memperoleh makna yang lebih mendalam sesuai dengan latar penelitian. Penggunaan pendekatan kualitatif dalam penelitian ini didasarkan pula atas pertimbangan agar: (1) lebih mudah menyesuiakan jika berhadapan dengan kenyataan ganda; (2) dapat menyajikan langsung hakikat hubungan antara peneliti dengan responden; (3) lebih peka dan lebih dapat menyesuaikan diri dengan banyak penajaman pengaruh bersama dan terhadap pola-pola nilai yang dihadapi.

Penelitian ini merupakan studi kasus di MAN Insan Cendekia Provinsi Jambi yang merupakan salah satu madrasah aliyah negeri yang ada di provinsi Jambi, lebih tepatnya berada di wilayah Pijoan Kabupaten Muaro Jambi. Penelitian dimulai dengan observasi awal lokasi penelitian, dimaksudkan untuk mengenali secara pasti mengenai tempat dilaksanakannya penelitian. 
Khusus mengenai sumber data yang berupa subjek atau sampel manusia, pemilihannya dilakukan secara purposif dijelaskan oleh Lincoln dan Guba sebgaimana dikutif oleh Moleong (2010: 34), bahwa peneliti mulai dengan asumsi bahwa konteksnya sendiri, dan peneliti sangat erat kaitannya dengan faktor-faktor kontekstual.

Berdasarkan prosedur sampling, maka yang menjadi subjek penelitian ini adalah kepala sekolah di madrasah tersebut yang berjumlah 1 orang, yang merupakan informan kunci bagi penelitian penulis. Sedangkan sebagai informan tambahan penulis tetapkan kepala sekolah dan 6 orang guru, dan 2 orang tenaga administrasi.

Penelitian ini direncanakan melalui beberapa tahapan, yakni mulai dari : Tahap persiapan, yang terdiri atas survei literatur, survei lokasi penelitian, pengidentifikasian data awal, dan pengajuan proposal. Tahap Pelaksanaan, yang terdiri atas pengumpulan data, pengolahan data, analisis data, dan penyusunan laporan awal. Tahap penyusunan laporan penelitian, yang terdiri atas persiapan seminar dan pelaksanaan seminar, penyusunan laporan akhir, penggandaan laporan, dan penyerahan laporan akhir ke Lembaga Penelitian dan Pengabdian kepada Masyarakat (LP2M) Universitas Jambi.

Pengumpulan data penelitian ini menggunakan tiga teknik utama, yaitu observasi, wawancara, dan studi dokumentasi.

Observasi

Observasi penulis lakukan secara berkelanjutan agar diperoleh informasi dari tangan pertama mengenai masalah yang diteliti dan kondisi MAN Insan Cendekia Provinsi Jambi. Untuk itu, penulis melakukan pengamatan partisipasi aktif dan pasif secara bergantian dengan memperhatikan sifat situasi dan peristiwa yang diamati serta keterlibatan penulis dengan responden.

Pelaksanaan wawancara pada prinsipnya dimaksudkan untuk mendapatkan data yang cukup sehubungan dengan pokok masalah penelitian yang telah diidentifikasi. Kegiatan wawancara ini penulis lakukan secara terus menerus dengan responden dalam berbagai situasi, meskipun kadangkala dilakukan pula dalam situasi yang khsusus.

Selain observasi dan wawancara, penulis menggunakan pula teknik pengumpulan data melalui studi dokumentasi. Data yang diperoleh dari studi dokumentasi, penulis manfaatkan sebagai bahan triangulasi untuk pengecekan kesesuaian data.

Proses pengumpulan data dalam penelitian ini penulis tempuh melalui tahap orientasi dan overview, tahap eksplorasi (focused exploration), dan tahap member check.

Tahap pertama, orientasi dan overview. Pada tahap ini penulis mencari dan mengumpulkan informasi yang diperlukan untuk menetapkan fokus penelitian. Tahap kedua, eksplorasi (focused exploration). Pada tahap ini, penulis mempertajam fokus penelitian agar pengumpulan data lebih terarah dan spesifik. Tahap ketiga, member check. Dimaksudkan untuk mengecek kebenaran data atau informasi yang dikumpulkan. Tahap ini merupakan tahap untuk memperoleh kredibilitas hasil penelitian.

Untuk mengecek kesahihan atau keterpercayaan data penelitian ini, penulis menggunakan kriteria sebagai berikut: (1) kredibilitas/derajat kepercayaan; transferabilitas/ keteralihan; konfirmabilitas/ kepastian.

Untuk memeriksa kesahihan data hasil penelitian ini penulis menempuh caracara berikut ini. 1. Ketekunan Pengamatan, 2. Triangulasi, 3. Member Check, 4. Audit Trail.

Analisis data yang penulis lakukan, mengikuti proses sebagaimana yang dianjurkan oleh Moleong (2010: 37), yaitu dimulai dengan menelaah seluruh data yang tersedia dari berbagai sumber, yaitu dari wawancara dan pengamatan yang sudah 
dituliskan dalam catatan lapangan, dokumen pribadi, dokumen resmi, gambar, foto, dan sebagainya. Adapun prosedur analisis data yang penulis tempuh dalam penelitian ini terdiri atas empat langkah berikut ini.

Reduksi data dilakukan dengan cara memilih data yang sudah disusun dalam laporan, kemudian disusun kembali dalam bentuk uraian terperinci.

Dalam tahap ini penulis membuat batasan untuk setiap satuan data, kemudian mengkodenya sehingga data yang sudah diperoleh ditransformasikan dan diorganisasi ke dalam unit-unit berdasarkan karakteristiknya.

Dalam tahap kategorisasi data ini penulis memilah-milah sejumlah unit menjadi satu kategori tertentu berdasarkan kesamaan karakteristiknya.

Tahap interpretasi merupakan upaya penulis memaknai data yang telah dikategorisasi dan menggambarkan makna analitik atas unit dan kategori serta keterkaitannya antara satu dengan lainnya.

\section{PEMBAHASAN}

Implementasi supervisi akademik di MAN Insan Cendekia Provinsi Jambi

Berdasarkan hasil observasi dan wawancara yang penulis lakukan kepada subjek penelitian, dapat dikemukakan bahwa implementasi supervisi akademik di MAN Insan Cendekia Provinsi Jambi dilaksanakan dalam bentuk sebagai berikut:

\section{Supervisi Berdasarkan Pengamatan Langsung Kegiatan Mengajar di Kelas}

Salah satu bentuk supervisi akademik yang dilakukan oleh kepala MAN Insan Cendekia kepada para guru ialah dengan melakukan pengamatan langsung ketika mengajar di kelas, hal itu berdasarkan hasil wawancara penulis dengan kepala madrasah pada tanggal 1 Agustus 2017 sebagai berikut:
"Saya secara rutin melakukan supervisi akademik kepada para guru, salah satu caranya ialah dengan mengamati secara langsung ketika mereka mengajar di kelas. Berdasarkan hasil pengamatan tersebut, saya kemudian memberikan masukan kepada guru bersangkutan mengenai berbagai kelemahan yang terdapat dalam pelaksanaan kegiatan belajar mengajar yang telah dilakukannya. Masing-masing guru mendapatkan giliran untuk diobservasi sesuai dengan jadwal supervisi yang telah ditetapkan, dan masing-masing guru mendapatkan giliran satu kali pada tiap semester."

Penjelasan kepala madrasah di atas sesuai pula dengan hasil observasi penulis pada tanggal 3 Agustus 2017, yang mana pada waktu melakukan kunjungan lapangan penulis melihat ibu Rafidah, S.S.I yang mendapat giliran supervisi. Terlihat ibu Rafidah, S.S.I sedang melaksanakan kegiatan belajar mengajar di kelas yang diamati langsung oleh kepala madrasah, dan terlihat kepala madrasah melakukan pengamatan secara intens sambil mencatat beberapa hal mengenai pelaksanaan kegiatan belajar mengajar tersebut.

Hasil obervasi penulis dan hasil wawancara dengan kepala madrasah di atas sesuai pula dengan penjelasan yang disampaikan oleh ibu Rafidah, S.S.I dalam hasil wawancara (3 Agustus 2017) sebagai berikut:

"Ya, setiap guru yang ada di MAN Insan Cendekia ini sudah positif mendapatkan giliran disupervisi oleh bapak kepala madrasah, termasuk saya juga mendapatkan giliran tersebut, seperti yang baru saja saya lakukan di kelas, ya, seperti itulah prosesnya, kepala madrasah mengamati secara langsung ketika kami mengajar di kelas, nanti berdasarkan hasil pengamatannya kita diberikan masukan oleh kepala madrasah mengenai berbagai kelemahan kita dalam mengajar"

\section{Supervisi Dengan Peninjauan Kerja Harian}


Bentuk lain dari supervisi akademik yang dilakukan oleh kepala madrasah kepada para guru ialah dengan melakukan peninjauan kerja hairan, hal itu berdasarkan hasil wawancara penulis dengan kepala madrasah (1 Agustus 2017) sebagai berikut:

"Selain dari melakukan pengamatan secara langsung ke kelas secara bergiliran sesuai dengan jadwal yang telah ditetapkan, maka saya juga melakukan peninjauan kerja harian kepada para guru, maksudnya ialah bahwa setiap hari saya berkeliling ke ruangan guru melakukan pemantuan terhadap mereka mengenai berbagai terkait hal-hal yang seharusnya mereka lakukan sebagai seorang guru profresional, seperti memeriksa tugas siswa, membaca dan mematangkan materi ajar, diskusi dengan rekan sejawat, dan lain-lain."

Penjelasan kepala madrasah tersebut sejalan dengan hasil observasi penulis (3 Agustus 2017), yang mana penulis melihat kepala madrasah melakukan kunjungan ke ruangan kerja guru, dan terlihat mereka melakuan komunikasi mengenai berbagai hal terkait tugas sehari-hari sebagai seorang guru.

Hasil obervasi penulis dan hasil wawancara dengan kepala madrasah di atas sesuai pula dengan penjelasan yang disampaikan oleh ibu Gunawan, S.Pd dalam hasil wawancara (3 Agustus 2017) sebagai berikut:

"Bapak kepala madrasah selalu mengunjungi ruangan guru bersama atau ruang kerja guru setiap hari, dan setiap beliau ke sini selalu mengecek, melakukan komunikasi atau tanya jawab dengan mengenai berbagai hal terkait proses belajar mengajar, dan mengenai hal-hal penting lainnya."

\section{Supervisi dengan Pemeriksaan Perlengkapan Mengajar}

Selain dari dua cara di atas, kepala madrasah juga melaksanakan supervisi akademik dengan cara pemeriksaan perlengkapan mengajar. Hal itu sesuai dengan penjelasan kepala madrasah dalam hasil wawancara (14 Agustus 2017) sebagai berikut:

"Cara lain yang saya lakukan untuk melaksanakan supervisi akademik adalah dengan memeriksa perlengkapan mengajar masing-masing guru. Saya ingin memastikan apakah para guru memiliki perlengkapan mengajar atau tidak. Dan sejauh ini Alhamdulillah para guru yang ada di MAN Insan Cendekia ini selalu memiliki perlengkapan mengajar."

Kepala madrasah menambahkan penjelasannya bahwa pemeriksaan perlengkapan mengajar diberlakukan kepada semua guru tanpa terkecuali, baik kepada guru senior maupun kepada guru junior. Mengenai waktu pemeriksaan dijelaskan oleh kepala madrasah bahwa dilaksanakan secara bergantian hingga semuanya mendapat giliran.

Penjelasan kepala madrasah di atas sama dengan pengakuan yang disampaikan oleh Melia Fitri Yani, seperti yang terangkum dalam hasil wawancara (20 Agustus 2017) berikut:

"Bapak kepala madrasah selalu melakukan pemeriksaan dokumendokumen perlengkapan mengajar. Ia selalu menegaskan jangan lengah untuk menyiapkan perlengkapan mengajar, karena apa yang kita laksanakan di dalam kelas berdasarkan apa yang kita rencanakan secara tertulis di dalam perlengkapan mengajar kita. Dan saya Alhamdulillah selalu menyiapkan perlengkapan dan saya selalu siap untuk diperiksa mengenai perlengkapan mengajar."

Keterangan dari hasil wawancara di atas sejalan pula dengan apa yang penulis lihat dalam kegiatan observasi (14 Agustus 2017), yang mana penulis menemukan bahwa di meja kepala madrasah terdapat beberapa perlengkapan mengajar para guru, dan ketika penulis melalukan observasi kepala madrasah juga baru saja selesai memeriksa salah satu perlengkapan mengajar guru. 


\section{Supervisi dengan Dialog Akademis}

Implementasi supervisi akademik pada MAN Insan Cendekia selain dari yang telah dijelaskan diatas juga dalam bentuk dialog akademis. Hal itu dapat diperhatikan dari keterangan yang disampaikan oleh kepala madrasah dalam hasil wawancara (14 Agustus 2017) sebagai berikut:

"Untuk memvariasikan pelaksanaan supervisi akademik kepada para guru di MAN Insan Cendekia ini saya sesekali melakukan dialog akademis kepada para guru, teknis pelaksanaannya bersifat kondisional, yaitu tidak terlalu formal. Terkadang saya menunjuk guru secara acak untuk datang ke ruang kerja saya untuk berdiskusi secara akademis mengenai berbagai permasalahan yang dirasakan dan dihadapi dalam pelaksanakaan kegiatan belajar mengajar. Dan terkadang saya yang mendatangi ruang kerja guru untuk melakukan dialog secara insidentil."

Penjelasan dari kepala madrasah terbsebut sejalan pula dengan penjelasan yang disampaikan oleh M. Safar, S.Kom dalam hasil hasil wawancara (20 Agustus 2017) sebagai berikut:

"Ya, sesekali kami dipanggil oleh kepala sekolah, dan kami diajak berdialog atau berdiskusi mengenai perihal pelaksanaan kegiatan belajar mengajar, dan mengenai berbagai hal terkait tugas dan tanggung jawab sebagai seorang guru. Maka dalam pembicaraan itu saya menjelaskan mengenai apa yang saya rasakan baik dari segi kemajuan-kemajuan peserta didik, maupun berbagai kendala dalam pelaksanaan kegiatan belajar mengajar, dan juga berbagai informasi penitng lainnya."

\section{Supervisi melalui Pengisian Angket}

Selain dari empat cara di atas, cara berikutnya yang digunakan oleh kepala madrasah MAN Insan Cendekia dalam melakukan supervisi akademik kepada para guru adalah dengan memberikan angket kepada para guru, dan para guru diminta untuk mengisi angket tersebut. Hal dapat diperhatikan dari pernyataan kepala madrasah dalam hasil wawancara (14 Agustus 2017) berikut ini:

"Saya juga memberikan angket kepada para guru untuk diisi, dari apa yang mereka isi maka mendapat masukan informasi mengenai apa yang mereka lakukan sebagai seorang guru di MAN Insan Cendekia ini. Dan berangkat dari hasil angket tersebut dapat pula disampaikan berbagai masukan penting kepada para guru demi kemajuan yang lebih baik."

Penjelasan dari kepala madrasah di atas sejalan pula dengan penjelasan yang disampaikan oleh Maryana, dalam hasil hasil wawancara (20 Agustus 2017) berikut:

"Di setiap tahun ajaran kami selalu diberikan angket, yang berisi pernyataan berbagai hal mengenai tugas dan tanggung jawab sebagai seorang guru, dan semua guru ikut mengisi angket tersebut, kemudian diserahkan ke kepala sekolah."

Penjelasan guru dan kepala madrasah di atas sesuai pula dengan apa yang penulis temui dalam kegiatan observasi (16 Agustus 2017), yang mana penulis melihat bahwa memang ada selebaran angket yang diberikan oleh pihak kepala madrasah kepada para guru. Dan penulis juga melihat secara langsung bahw ada sejumlah angket yang telah diisi oleh para guru. Bahkan kepala madrasah melalui stafnya memberikan photo kopy draft angket supervisi kepada penulis.

\section{Kendala Implementasi Supervisi Akademik di Man Insan Cendekia Provinsi Jambi}

Berdasarkan hasil pengumpulan data yang penulis lakukan kepada subjek penelitian, dapat dikemukakan bahwa kendala implementasi supervisi akademik di MAN Insan Cendekia Provinsi Jambi sebagai berikut: 


\section{Banyaknya Tugas dan Tanggung Jawab Kepala Madrasah}

dengan kepala madrasah dapat
dikemukakan bahwa salah satu kendala implementasi supervisi akademik di MAN Insan Cendekia adalah banyaknya tugas dan tanggung jawab lain dari kepala madrasah, hal itu terungkap dalam hasil wawancara (11 September 2017) sebagai berikut:

"Diantara kendala yang saya rasakan dalam implementasi supervisi akademik di MAN Insan Cendekia ini adalah banyaknya tugas dan tanggung jawab saya sebagai seorang kepala sekolah. Yang mana saya dihadapkan kepada agenda kerja yang tidak sedikit, dan semuanya sama-sama penting. Jadi saya harus bekerja ekstra keras untuk melaksanakan segala tugas dan kewajiban saya tersebut. Maka saya merasa kekurangan waktu untuk bisa melaksanakan supervisi akademik kepada para guru secara lengkap dan secara merata"

Pernyataan kepala madrasah diperkuat oleh keterangan yang diberikan oleh Didik Setiaji, seperti yang tertuang di dalam hasil wawancara (14 September 2017) sebagai berikut:

"Sebenarnya tidak ada kendala yang serius yang dihadapi oleh Bapak kepala madrasah dalam melakukan supervisi kepada para guru. Hanya saja memang bapak kepala madrasah memiliki agenda kerja yang cukup padat, sehingga cukup kewalahan untuk melakukan supervisi akademik dengan frekwensi lebih sering"

Keterangan dua hasil wawancara di atas sesuai pula dengan hasil observasi penulis, yang mana penulis melihat bahwa kepala madrasah memiliki agenda kerja yang cukup padat. Tidak hanya agenda kerja internal tetapi juga ekstenal.

Berdasarkan hasil penelitian tersebut dapat dipahami bahwa apa yang telah dilakukan oleh kepala MAN Insan Cendekia Provinsi Jambi telah memberikan bukti yang meyakinkan, hal itu terbukti bahwa secara kinerja akademik guru berjalan dengan baik. Para guru terlihat bekerja dengan semangat tinggi, dan dapat dikatakan pula bahwa para guru bekerja sesuai dengan koridor atau aturan kerja yang telah ditetapkan oleh MAN Insan Cendekia.

Bagusnya kinerja para guru di MAN Insan Cendekia tentu tidak terlepas dari kepemimpinan kepala madrasah yang baik, dalam hal ini kepala madrasah telah menjalan fungsinya sebagai supervisor internal dengan baik, sehingga melahirkan kinerja guru yang positif yang sesuai dengan apa yang diinginkan oleh madrasah.

Ketika pengelolaan dan pelaksanaan supervisi telah dilaksanakan dengan baik, maka wajar jika MAN Insan Cendekia Provinsi Jambi menunjukkan hasil prestasi yang membanggakan. Hal itu terbukti dari prestai yang diraih oleh para siswa yang luar biasa, tidak sedikit pula para alumninya yang melanjutkan pendidikan ke universitasuniversitas pavorit di berbagai tempat di Indonesia, bahkan beberapa orang diantaranya melanjutkan studinya ke luar negeri.

\section{KESIMPULAN}

Berdasarkan uraian yang telah penulis sajikan pada hasil penelitian di atas, dapatlah diambil kesimpulan: 1. Implementasi Implementasi supervisi akademik di MAN Insan Cendekia Provinsi Jambi dilaksanakan dalam bentuk sebagai berikut: a. Supervisi berdasarkan pengamatan langsung kegiatan mengajar di kelas. b. Supervisi dengan peninjauan kerja harian. c. Supervisi dengan pemeriksaan perlengkapan mengajar d. Supervisi dengan dialog akademis. e Supervisi melalui pengisian angket. 2. Kendala implementasi supervisi akademik di MAN Insan Cendekia Provinsi Jambi adalah sebagai berikut: a. Banyaknya tugas dan tanggung jawab lain dari kepala madrasah. 
Berdasarkan hasil penelitian ini maka penulis menyarankan kepada pihak MAN Insan Cendekia Provinsi Jambi agar bisa mempertahankan proses pelaksanaan supervisi akademik yang sudah baik ini, dan alangkah lebih baiknya jika ditingkatkan untuk menjadi lebih baik lagi.

\section{DAFTAR PUSTAKA}

Arikunto, Suharsimi. (2007) Dasar-Dasar Supervisi, Jakarta: Rineka Cipta.

Anonim. (2005). Undang-Undang Sistem Pendidikan Nasional 2003: UU RI No.20 tabun 2003, cet.ke-2, Jakarta: Sinar Grafika.

Basrowi \& Suwandi. (2008). Memahami Penelitian Kualitatif, Jakarta: Rineka Cipta.

Manab, Abdul. (2015). Penelitian Pendidikan: Pendekatan Kualitatif, Yogyakarta: Kalimedia.

Masaong, Abd. Kadim. (201). Supervisi Pembelajaran dan Pengembangan Kapasitas Guru, Alfabeta: Bandung,
Mukhtar \& Iskandar. (2009). Orientasi Baru Supervisi Pendidikan, Jakarta: Gaung Persada Press.

Mulyasa, E. (2015). Manajemen Kepemimpinan Kepala Sekolah, Jakarta: Bumi Aksara.

Mulyono. (2007). Pedoman Administrasi Bagi Lembaga Pendidikan SMA, Probolinggo, Diklat Jardiknas.

Moleong, Lexy J. (2010). Metodologi Penelitian Kualitatif, Bandung: Remaja Rosda Karya.

Priansa, Donni Juni \& Rismi Somad. (2014). Manajemen Supervisi dan Kepemimpinan Kepala Sekolah, Bandung: Alfabeta.

Purwanto, Ngalim. (2008). Administrasi dan Supervisi Pendidikan. Bandung: Remaja Rosda Karya.

Syaiful Sagala. (2008). Administrasi Pendidikan Kontemporer. Bandung: Alfabeta.

Sugiyono. (2008). Memahami Penelitian Kualitatif, Bandung: Alfabeta. 